Agro-Science Journal of Tropical Agriculture, Food, Environment and Extension Volume 16 Number 3 (September 2017) pp. $51-62$

ISSN 1119-7455

\title{
CLIMATE CHANGE PERCEPTION, AWARENESS AND ADAPTATION DECISION AMONG FOREST COMMUNITIES IN NIGERIA
}

\author{
Onyekuru, ${ }^{1}$ N.A and Marchant, ${ }^{2} \mathrm{R}$ \\ ${ }^{1}$ Food Security and Sustainable Environment Research Group, Environment and Development \\ Research Unit, Department of Agricultural Economics University of Nigeria, Nsukka \\ ${ }^{2}$ York Institute for Tropical Ecosystem (KITE), Environment Department University of York, \\ University Road, York, UK, YO10 5DD. 2 Environment Department, University of York, York, UK \\ Corresponding author: Onyekuru N. A. anthony.onyekuru@unn.edu.ng, chiakatony@yahoo.com \\ Rob Marchant: robert.marchant@york.ac.uk
}

\begin{abstract}
In recent time the perception of climate change is beginning to gain recognition in policy circles, due to the need to understand how individuals' experiences and attributes influence their understanding of climate change and their adaptation processes.This is important to development well-targeted policies and interventions among the forest poor. The perception of climate change and adaptation decision of forest communities in Nigeria were analyzed using the logit model. Results show that over88\% of the respondents have perceived climate change in one form or the other in all the ecological regions except in the montane forest where only 33\% has.Over $84 \%$ are aware of changes in forest resource use over time except in the montane forest where only $24 \%$ did. Ability to notice climate change was positively associated with spring rainfall, but negatively associated with education, net income, summer and fall precipitation. Decision to take up innovation was positively associated with access to electricity, number of years of forest use, winter rainfall and temperature, and negatively associated with summer rainfall. Spring rainfall has a $2.4 \%$ likelihood of positively influencing the chance of noticing climate change, while it is negative with summer and fall rainfall; 0.4 and $1.7 \%$ respectively.Access to electricity, number of years of forest use and winter rainfall likely increase innovation adoption by $18.6,0.5$ and $1.5 \%$ respectively, while summer precipitation reduces the likelihood of adoption by $0.4 \%$.It is therefore important for stakeholders to synchronizethese information in order to help build the adaptive capacity of forest communities not only in Nigeria but across the developing world.
\end{abstract}

Keywords: Adaptive capacity, Adoption, Forest resources, Innovation, Policy.

\section{INTRODUCTION}

Farmers respond to climate stimuli (Bradshaw et al., 2004; Belliveau et al., 2006; Maddison, 2007; Nhemachena and Hassan, 2007). Though climate change is perceived differently at different levels of conceptualization depending on socio economic variables, location and livelihood activity (Digg, 1991; West et al. 2007). Depending on the perception and awareness, farmers make certain changes on their livelihood patterns that occur through climate change (Kessler, 2006). Experience in Africa suggests that, in addition to agronomic performance, farmers perceptions are often determinants of adoption (Wortman and Kirungu, 1999). When a new technology or practice offers genuine benefit to stakeholders, slow adoption rate can be a source of worry to policy makers, extension practitioners, especially when they have put everything in place to facilitate effective adoption (Onyekuru, 2008). This situation no doubt arises when there is a divergence between the attributes of the innovation and those of the adopter. Adaptation in its simplicity is how perception of climate change is translated into decision-making process (Bryant et al., 2000) by different individuals in different sectors. Their perception determines the course of action taken, thus different individuals may have different courses of action consequent on an impact, depending on their different characteristic and prevailing environmental conditions. Thus, in order to adapt to climate change, individuals must first perceive that changes are taking place (Madison, 2007; As faw and Lipper, 2011) and their choices and farming practices are based on a set of expectations about weather, markets and other factors which are based upon their own experiences (Madison, 2007), as well as information they may obtain from a range of sources including extension agents. Asfaw and Lipper (2011) and Pannell (1999) point out that if farmers are to adopt land 
Climate Change Perception, Awareness and Adaptation Decision

conservation techniques they must first be aware that the technology exists and perceive that it is profitable. Understanding why farmers do what they docan improve the quality of policy and programming decisions at various levels (Leagans, 1979). Environmental behaviors are more likely to occur when an individual believes there is a problem (Lubell et al., 2007; Haden et al., 2012). Perceptions of climate change risk have direct influence on responses to climate policy risks (Niles et al., 2013), thus farmers who believe that climate change is risky are more likely to support and participate in policies that aim to address climate change. A more complete understanding of how farmers make decisions is therefore of interest to policy makers and social scientistsalike (Edwards-Jones and McGregor, 1994). Thus, there is a need for a clear understanding of the circumstances under which adoption thrives, these are inherent in the perceptions and characteristics of the adopter, the nature of the environment and the attributes of the innovation itself (Onyekuru, 2008). Personal characteristics and economic conditions influence farmers' response to climate change and variability - poor farmers are likely to take measures to ensure their survival, while wealthier farmers make decisions to maximize profits (Ziervogel et al., 2006).Although there has been considerable research on farmersbehavior, surprisingly there has been little empirical quantitative analysis on farmers' individual adaptation decisions, especially addressing the complex, forward-looking and site specific characteristics of adaptation processes (Below et al., 2012), or on how farmers' climate change beliefs impact on their plans for the future (Wheeleret al., 2013). To ensure the design of sound policies that minimize unintended consequences, it is important to understand the influences underlying farmers intended strategic responses at the micro level; in particular how farmers' beliefs drive change (Wheeler et al., 2013).

Since people's perceptions of climate change, is beginning to gain recognition in policy circles, understanding adaptation processes is therefore needed for the development of welltargeted policies (Beilin et al., 2012; Below et al., 2012; Nicholas and Durham, 2012).Experience has shown that there are numerous examples of promising innovations that have not been taken up by farmers. There are several factors that influence this, that is the crux of this paper. And because adaptation is often conceptualized as a site specific phenomenon, many authors call for local-level analysis to gain a better understanding of the fundamental processes underlying adaptation and for better targeting of adaptation policies by national and local, NGOs and bi-lateral donors (Smit and Wandel, 2006, Boko et al;, 2007, Mano and Nhemachena, 2007). Hence the need to have a good understanding of conditions which influence perceptions and the adoption process.

\section{Theoretical framework}

Appropriate technologies are not always adopted, even where the need is obvious (Guerin, 1999). The rate of adoption of most technologies depend on several personal and socioeconomic characteristics (Tenge et al., 2004; De Graaff et al., 2008). Farmers consider a variety of factors in deciding whether or not to adopt particular practices, these include various socio-economic, cultural and institutional, as well as biophysical and technical factors (McDonald and Brown, 2000; Soule et al., 2000). According to Lapar and Pandey (1999), such factors could be farmer-specific, farmspecific and technology-specific. Farmerspecific factors include the goals of the farmer; at a broader level, the socio-economic milieu under which production takes place determines the resource base by allowing resource augmentation through market participation (Lapar and Pandey, 1999). Farm-specific factors are related to the biophysical characteristics of the production systems such as soil characteristics and climate, as well as the broader characteristics of the production system and technology-specific factors are the attributes of the technology available to the farmer to assist him in his production process. The choice will depend on three main aspects: firstly, the characteristics of the innovation themselves; secondly, the personal attitudes and preferences of the individual farmer and, thirdly, the frame conditions such as the financial situation of the farm, the specific climatic and regional site conditions or the general legal restrictions and policy settings (Sattler and Nagel, 2008).

Adaptation to climatic changes requires a combination of various individual responses at the farm-level, it vary from household to households and region to region based on existing support system to increase the resilience of affected individuals (Mengistu, 2011).Adoption was first measured by Rogers(1958) who used the time at which a practice was adopted as a classification criterion. Ervin and Ervin (1982) considered adoption a decision-making process and tried to include a wide range of personal-, physical-, institutional- and economic factors into their classical conservation decision model. It considers three stages: (1) the perception of the problem,(2) the decision to use the practices and (3) the determination of outcome of effort. Even when farmers perceive the problem and are aware of possible solutions, they can decide not to use practices. Many different factors, known as the barriers to adoption, can lead to the non-acceptance of alternative. To understand the driving forces behind human behaviour in relation to the adoption 
Onyekuru, N.A and Marchant. R,

process, it is important to understand the rationale behind what motivates people to undertake action (Kessler, 2006). These reasons are inherent in their perception and experience about a situation. Deci and Ryan (1985) distinguish between intrinsic motivation (doingsomething because it is inherently interesting or enjoyable) and extrinsic motivation (doing something because a reward is expected). Intrinsic (or self-determined) motivation can promote sustained environmental behaviour (Osbaldiston and Sheldon, 2003), whileextrinsic motivations provide less durable changes (De Young, 1996).Decision-making is also strongly influenced by non-rational and subjective aspects (Kessler, 2003). Individuals feelings and aspirations (Giampietro, 1997) requires a favourablemental attitude (Leagans, 1979). Thus, the household's ability to adopt generally depends on a wide range of obvious socio-economic factors, willingness is often also influenced by strictly personal and behavioral factors (Kessler, 2006; Feder et al. 1985).

Though some individuals will never adoptpractices, even if they are economically feasible, they will be regarded by many people as ignorant or laggards (Kessler, 2006). But Vanclay and Lawrence (1994) argue that some aspects of individuals' resistance must be considered legitimate aspects of human behaviour, and not as deficiencies in their attitudes. In support of this view point Pannel (1999) asserts that it can be constructive to recognize when slow adoption of a new technology may be the result of a rational wait for more high-quality information about its value to become readily available, rather than some intractable attitudinal or social barrier to change. Waiting for more information to reduce uncertainty (andtheriskofmaking a costly wrong decision) can be of more economic value than early adoption; sometimes even when the individual already considers it more likely than not that the new innovation will be profitable (Dong and Saha, 1998). Thus, Llewellyn (2007) advocates for a closer attention to information-related factors about the innovation in adoption decision process.

\section{MATERIALS AND METHODS Sampling}

Data were collected from 450 rural households, sampled from five broad ecological regions in Nigeria (Fig.1). Using a structured questionnaire, interviews focused on assessing the socio economic attributes of respondents, how they have been impacted upon by climate change and what their perceptions of climate change and adaptation decision process are. Based on the relative size of the population which they support, and the prevalence of forest cover, 150, 100, 100, 50 and 50 households were sampled from the rainforest, mangrove forest, Guinea savanna, montane forest and Sudan savanna zones respectively (Figure 1). The consideration in the sample selection here was not necessarily to get a representative weighted sample, but to get sufficient sample across each zone for the analysis. For the rainforest zone the Cross River high forest was chosen as this is the only area of surviving lowland rainforest cover, not just in Nigeria, but across West Africa. Communities were selected from the respective states considering the availability of knowledgeable research assistants in the area who could understand the local languages. Communities were selected based on information from local informants on their reliance on forest resources. Five communities were selected from each of the rainforest and mangrove forest areas, four from Guinea savanna, three from montane and two from Sudan savanna ecological region. Communities were chosen using a random draw from all possible communities in the target areas. In each community households were randomly selected using the communities' roll calls; different households from the roll call were selected at random intervals until the required number of households per community was reached (this was directly proportional to the total population of the different communities). Structured questionnaires were administered on a one to one basis, with the household heads, or other knowledgeable members of the households, who were conversant with forest resource use by the household and the wider community. To check for interviewer bias and ensure data consistency and compatibility, the addresses and mobile phone numbers of each respondent were collected and information supplied by the interviewer randomly crosschecked in all zones. The data collected were coded and screened for consistency and analyzed using STATA.

\section{Theoretical model}

Several models have been employed to measure climate change perception and adaptation decision. Binary logistic model. In this study, due to the dichotomous nature of the dependent variables, a binomial logit model was used to explore associations between the socioeconomic and climatic attributes and climate change perception and adaptation decision, as was employed in the work of Mbaga-Semgalawe and Folmer (2000) in Tanzania. Logistic regression applies maximum likelihood estimation after transforming the dependent into a logit variable. In this way, logistic regression estimates the odds of a certain event (value) occurring, calculates changes in the $\log$ odds of the dependent, but not changes in the dependent itself as OLS regression does. According to Garson (2011), logistic regression has many analogies to OLS regression: logit coefficients correspond to ' $\beta$ ' coefficients in the logistic regression equation, the standardized logit 
coefficients correspond to beta weights and a pseudo $\mathrm{R}^{2}$ statistic is available to summarize the strength of the relationship. Goodness-of-fit tests such as the likelihood ratio test are available as indicators of model appropriateness, the Wald statistic is used to test the significance of individual independent variables. In the logit model the qualitative dependent variables assume discrete rather than continuous forms. Thus, dependent variable "Y" can lake only two values one and zero, thus depicting a binary outcome. The logit model is thus specified as follows:

$\mathrm{Y}^{*}=\sum \mathrm{x} \beta+\varepsilon, \varepsilon \sim \mathrm{N}(0,1)$ If $\mathrm{y}^{*}>0, \mathrm{y}=1$ If $\mathrm{y}^{*}<0$, $\mathrm{y}=0$

\section{Definition of variables}

The dependent variables in this estimation are defined to have two possible values: 1 , denotes the perception of climate change and decision to adapt while ' 0 ' denotes non perception and not adapting in two separate equations. Each of the dependent variable may be related to: household size, gender, age, number of years of forest use, level of education and occupation of household head, household net income from the forest, individual observation of climatic change, distance to the market, access to extension services, electricity, temperature and rainfall. The sign and size of the association between the dependent variables and the explanatory variables could vary from negative to positive and 0 to $100 \%$ respectively depending on the nature of the explanatory variables, economic theory and prevailing environmental conditions.

\section{Analytical procedure}

For this study, the dependent variables in the empirical estimation are perception of climate change and decision to adapt, while the explanatory variables are household size, gender, age, number of years of forest use, level of education and occupation of household head, household net income from the forest, temperature, rainfall, individual observation of climatic change, distance to the market, access to extension services and electricity and climatic variables; temperature and rainfall. In this analysis the explanatory variables were regressed against each of the adaptation options (dependent variables) to estimate how each of the explanatory variables influence climate change perception and the decision to adapt; the level and direction of association. Furthermore, the marginal effect analysis was performed to determine the likelihood (percent) of each explanatory variable influencing climate change perception and adoption decision and the results are presented below.

\section{RESULTS}

Results on climate change perception show that majority $(88 \%)$ of the respondents have noticed climate change in one form or the other in all the zones with the highest occurrence in the Sudan savanna and the least in the montane forest where only $33 \%$ has noticed climate change impact (Figs. 2 and 3). There was divers views among respondents about the concept of climate change, with most $(60.3 \%)$ having a clear understanding of the concept of climate change (Fig. 4). With respect to awareness of changes in forest resource use due to climate change in the different ecological regions most $(93 \%$ and $92 \%)$ of the respondents in the rainforest and Guinea savanna respectively have noticed changes, while in the mangrove and Sudan savanna all the respondents were in the affirmative. On the contrary only $24 \%$ of respondents in the montane forest ecological zone affirmed that they have noticed changes, while the rest have not. While in overall result shows that about $84 \%$ of all the respondents agreed to have noticed changes in forest resource use over time (Fig. 6). With respect to specific changes noticed in the forest, several kinds of shifts have been reported as is shown in table 1 . In the Sudan savanna the major issue has to do with shortage of fodder and herbs for their animals.

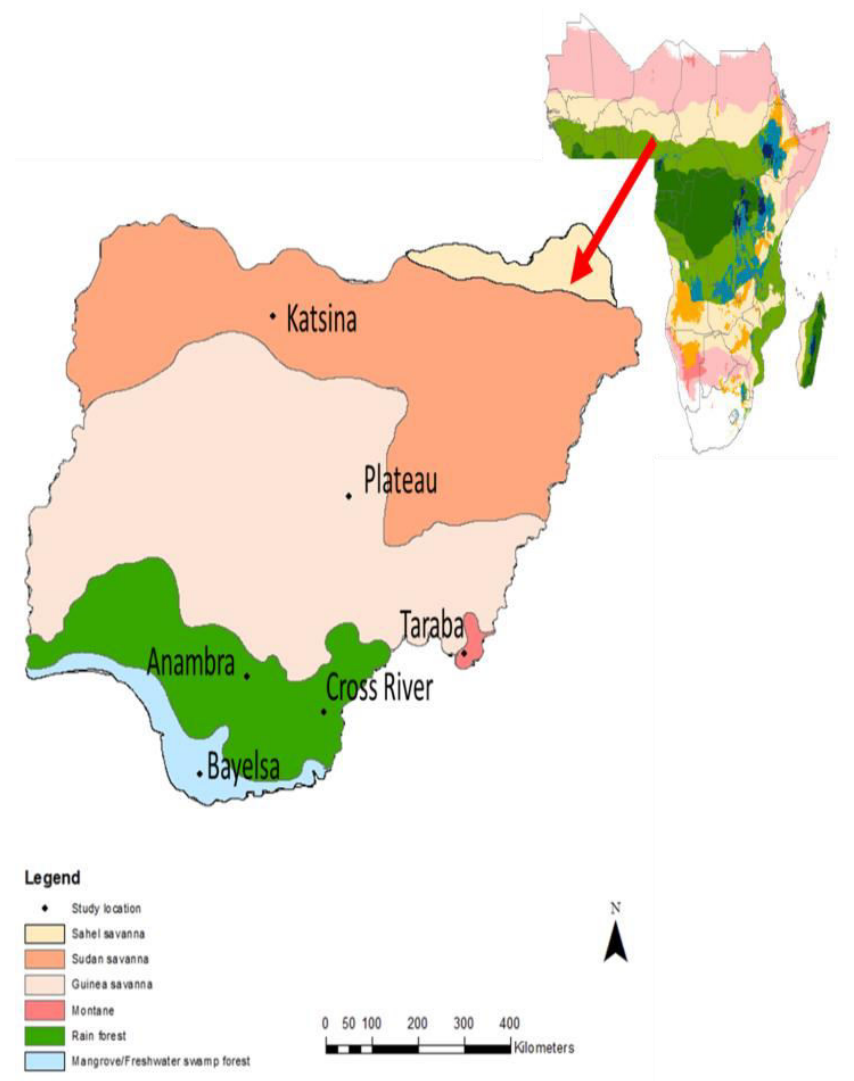

Figure 1: .Agro ecological map of Nigeria showing locations where communities were assessed 
Onyekuru, N.A and Marchant. R,

Table 1. Types of changes perceived in forest resource use

\begin{tabular}{|c|c|c|c|c|c|}
\hline \multirow[t]{2}{*}{ Types of changes } & \multicolumn{5}{|l|}{ Percentage } \\
\hline & Rainforest & mangrove & $\begin{array}{l}\text { Guinea } \\
\text { savanna }\end{array}$ & Montane & Sudan \\
\hline Bush fire & .5 & & 5 & & 5.5 \\
\hline Change of colour of leaves & & & & & 23.1 \\
\hline Decrease in herbs & & & & & 7.7 \\
\hline Decrease in productivity & 13.6 & 15.5 & & & \\
\hline Deforestation & 17.7 & 12.0 & 31 & 38.5 & \\
\hline Destruction of forest tourism & & & & 7.7 & \\
\hline Don't know & & 3.8 & & & \\
\hline Exploration by multinational companies & & 5.1 & & & \\
\hline Extinction of some forest plants and wildlife & 4.0 & & & & \\
\hline Fodder dries up fast & & & & & 15.4 \\
\hline Fruitlessness & & & 1.9 & & \\
\hline Grasses are shorter now & & & 7.0 & & \\
\hline Inadequate fodder & & & & & 15.4 \\
\hline Less honey than before & & & 8.2 & 7.7 & \\
\hline Less ogbono in the forest & & 9.6 & & & \\
\hline Low catch of crayfish & & 2.5 & & & \\
\hline Low fish catch in the ponds & & 1.9 & & & \\
\hline Low snails harvest like before & & 12.7 & & & \\
\hline Open forest without canopy & & 5.1 & 2.5 & & \\
\hline Over exploitation of trees & & & & 7.7 & \\
\hline Reduction in forest resources & & 17.7 & & & \\
\hline Reduction in the number of large trees & & 2.5 & 2.5 & & \\
\hline Some new species of plants have emerged & & & 10.8 & & \\
\hline Some tree spp and wildlife have disappeared & & & 29.1 & & \\
\hline The firewood dries faster & & & & & 7.7 \\
\hline The grasses dries up faster & & & & & 7.7 \\
\hline Too much charcoal making & & & & 38.5 & \\
\hline Vegetables are reducing & & & & & 15.4 \\
\hline
\end{tabular}

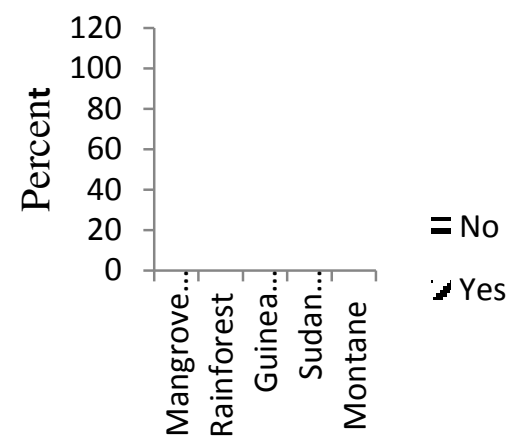

Agro-ecological regions

Figure 2: climate change perception in the different ecological zones

In the montane forest and Guinea savanna the problem has to do with reduction of forest cover which impacts on all other aspect of forest resources like honey output and fruit production. In the rainforest the major change experienced has to do with excessive deforestation which impacts on forest productivity and loss of biodiversity. In the mangrove the changes experienced has to do with loss in different mangrove forest resources and the excessive pressure from multinational oil companies on the forest. In terms of perception of

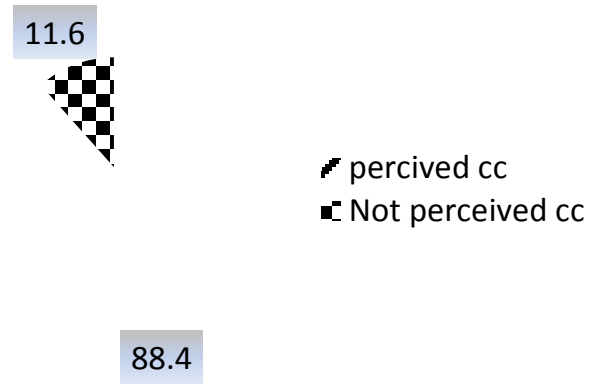

Figure 3: Overal climate change perception among forst communities in Nigeria

the extent of climate change impacts the phenomenon that are more prevalent are those associated with excessive rainfall, high temperature, dryness, loss of soil fertility and erratic pattern of rainfall (Table 2).

Results of the logistic regression show that increase in the ability to notice climate change was positively associated with spring rainfall and negatively associated with education, net income, summer and fall precipitation (Table 4). The decision to take up adaptation options was 
Climate Change Perception, Awareness and Adaptation Decision

positively associated with access to electricity, temperature, while it was negatively associated with summer rainfall. The marginal effect analysis (Table 5) shows that while increase in spring rainfall has a $2.4 \%$ likelihood of increasing the chance of noticing climate change, summer and fall precipitation have 0.4 and $1.7 \%$ likelihood of reducing the chance of noticing climate change. In number of years of forest use, winter rainfall and the case of deciding to adopt adaptation strategies increasing access to electricity, number of years of forest use and winter rainfall likely increase technological adoption by 18.6, 0.5 and $1.5 \%$ respectively, while increase in summer precipitation reduces the likelihood of adoption by $0.4 \%$.

Table 2. Perceptions about the extent of climate change impact

\begin{tabular}{|c|c|c|c|c|c|}
\hline Variables & $\mathrm{N}$ & Minimum & Maximum & Mean & Std. Deviation \\
\hline Thunder storms & 26 & 1 & 5 & 2.654 & 1.1981 \\
\hline Desertification & 5 & 1 & 5 & 2.8 & 1.4832 \\
\hline Heavy winds & 41 & 1 & 5 & 3.098 & 1.3929 \\
\hline Heat waves & 32 & 1 & 5 & 3.156 & 1.139 \\
\hline No or reduced harmattan & 66 & 1 & 5 & 3.318 & 1.0548 \\
\hline Uncertainties in the onset of farming season & 62 & 1 & 5 & 3.355 & 1.2024 \\
\hline Long period of harmattan & 66 & 1 & 5 & 3.379 & 1.2742 \\
\hline Increase in pests problems & 51 & 1 & 5 & 3.451 & 1.2052 \\
\hline Less rainfall & 25 & 1 & 5 & 3.48 & 1.4177 \\
\hline Increase weed infestation & 80 & 1 & 5 & 3.563 & 1.1783 \\
\hline Delay in the unset of rain & 104 & 1 & 5 & 3.644 & 1.1484 \\
\hline Drying up of stream and rivers & 6 & 3 & 5 & 3.667 & 0.8165 \\
\hline Long period dry season & 92 & 1 & 5 & 3.772 & 1.0701 \\
\hline Drought & 4 & 2 & 5 & 4 & 1.4142 \\
\hline High rate of disease incidence & 139 & 1 & 5 & 4.065 & 1.2289 \\
\hline Loss of soil fertility & 114 & 1 & 5 & 4.175 & 0.9977 \\
\hline Unusual early rains followed by weeks of dryness & 81 & 1 & 5 & 4.346 & 0.6356 \\
\hline Heavy and long period of rainfall & 78 & 1 & 5 & 4.359 & 1.0808 \\
\hline Higher temperature & 114 & 1 & 5 & 4.386 & 0.8467 \\
\hline Erratic rainfall pattern & 101 & 1 & 5 & 4.436 & 0.8651 \\
\hline Overflowing of streams and rivers & 10 & 3 & 5 & 4.5 & 0.7071 \\
\hline Floods and erosion & 97 & 2 & 5 & 4.536 & 0.7781 \\
\hline
\end{tabular}

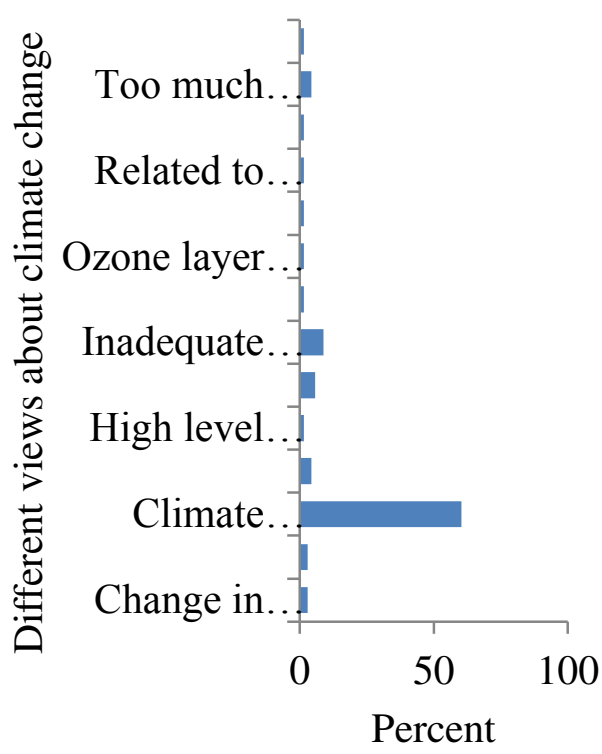

Figure 4: Ditterent views about the concept of over time

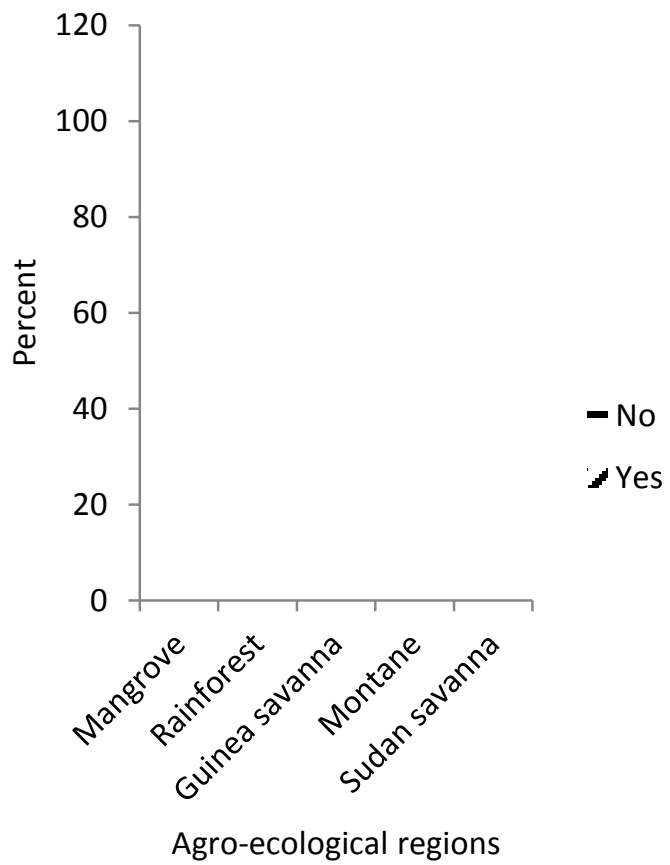

Figure 5: Awareness of changes in forest resources climate change among the forest dwellers 
Onyekuru, N.A and Marchant. R,

Table 3: Summary statistics of logistic regression

\begin{tabular}{|c|c|c|c|c|c|c|c|c|c|}
\hline \multirow[t]{2}{*}{$x^{2+2}$} & \multirow[t]{2}{*}{$\mathrm{N}$} & \multirow[t]{2}{*}{ Mini } & \multirow{2}{*}{ Max } & \multirow{2}{*}{ Mean } & \multirow{2}{*}{ Std. Dev. } & \multicolumn{2}{|c|}{ Skewness } & \multicolumn{2}{|c|}{ Kurtosis } \\
\hline & & & & & & statistic & Std.Error & Statistic & Std.Error \\
\hline Notice of climate change & 400 & 0 & 1 & 0.88 & 0.32 & -2.409 & 0.122 & 3.825 & 0.244 \\
\hline Adaptation decision & 400 & 0 & 1 & 0.74 & 0.44 & -1.091 & 0.122 & -0.814 & 0.244 \\
\hline Erosion control & 400 & 0 & 1 & 0.52 & 0.5 & -0.071 & 0.122 & -2.005 & 0.244 \\
\hline Agroforestry & 400 & 0 & 1 & 0.35 & 0.477 & 0.647 & 0.122 & -1.59 & 0.244 \\
\hline Changing timeofactivities & 400 & 0 & 1 & 0.46 & 0.499 & 0.152 & 0.122 & -1.987 & 0.244 \\
\hline Energycookstove & 400 & 0 & 1 & 0.11 & 0.308 & 2.573 & 0.122 & 4.644 & 0.244 \\
\hline Migration & 400 & 0 & 1 & 0.08 & 0.276 & 3.032 & 0.122 & 7.227 & 0.244 \\
\hline Irrigation & 400 & 0 & 1 & 0.24 & 0.43 & 1.198 & 0.122 & -0.567 & 0.244 \\
\hline Culturalpractice & 400 & 0 & 1 & 0.76 & 0.425 & -1.247 & 0.122 & -0.447 & 0.244 \\
\hline Household size & 400 & 1 & 9 & 4.21 & 2.551 & 0.398 & 0.122 & -0.973 & 0.244 \\
\hline Gender of Household head & 400 & 0 & 1 & 0.73 & 0.443 & -1.061 & 0.122 & -0.878 & 0.244 \\
\hline Age of household head & 400 & 18 & 86 & 48.55 & 13.981 & -0.043 & 0.122 & 0.246 & 0.244 \\
\hline Level of education of hhold & & & & & & & & & \\
\hline head & 400 & 0 & 25 & 9.39 & 5.265 & -0.061 & 0.122 & -0.709 & 0.244 \\
\hline Access to electricity & 400 & 0 & 1 & 0.59 & 0.492 & -0.38 & 0.122 & -1.865 & 0.244 \\
\hline Primary occupation & 400 & 0 & 1 & 0.75 & 1.05 & 6.866 & 0.123 & 59.183 & 0.245 \\
\hline $\begin{array}{l}\text { Number of years of forest } \\
\text { use }\end{array}$ & 400 & 1 & 60 & 19.9 & 10.729 & 0.916 & 0.122 & 1.431 & 0.244 \\
\hline $\begin{array}{l}\begin{array}{l}\text { Distance } \\
\text { (minutes) }\end{array} \\
\text { to the }\end{array}$ & 400 & 5 & 90 & 39.58 & 22.735 & 0.353 & 0.122 & -0.454 & 0.244 \\
\hline $\begin{array}{l}\text { Mode of transportation to } \\
\text { mkt } \\
\text { Net revenue from forest }\end{array}$ & 400 & 0 & 1 & 0.66 & 0.476 & -0.658 & 0.122 & -1.575 & 0.244 \\
\hline $\begin{array}{l}\text { products } \\
\text { prest }\end{array}$ & 400 & 5000 & 5500000 & 307893.2 & 532373.1 & 4.835 & 0.122 & 32.125 & 0.244 \\
\hline Extension visit (number) & 400 & 0 & 24 & 0.51 & 2.65 & 5.819 & 0.122 & 34.969 & 0.244 \\
\hline Springp & 400 & 21.43 & 222.9797 & 138.9699 & 67.22623 & -0.236 & 0.122 & -1.112 & 0.244 \\
\hline Summerp & 400 & 164.38 & 419.9431 & 283.2101 & 97.58997 & 0.2 & 0.122 & -1.442 & 0.244 \\
\hline Fallp & 400 & 37.05 & 285.1285 & 179.4544 & 88.75053 & -0.286 & 0.122 & -1.325 & 0.244 \\
\hline Winter & 400 & 0 & 40.98061 & 19.30199 & 18.54841 & 0.04 & 0.122 & -1.94 & 0.244 \\
\hline Springt & 400 & 29.8886 & 37.91707 & 33.30396 & 2.412259 & 0.568 & 0.122 & -0.67 & 0.244 \\
\hline Summert & 400 & 25.12281 & 32.86992 & 29.3436 & 2.060948 & -0.398 & 0.122 & 0.308 & 0.244 \\
\hline Fallt & 400 & 27.30877 & 33.5065 & 30.6768 & 1.75966 & -0.255 & 0.122 & -0.375 & 0.244 \\
\hline Winter & 400 & 28.26053 & 35.50583 & 32.52973 & 2.228178 & -0.347 & 0.122 & -0.453 & 0.244 \\
\hline
\end{tabular}

Table 4: Summary of logistic regression analysis

\begin{tabular}{|c|c|c|c|c|}
\hline & \multicolumn{2}{|c|}{$\begin{array}{l}\text { Notice of climate } \\
\text { change }\end{array}$} & \multicolumn{2}{|c|}{ Adaptation decision } \\
\hline Variables & Coef. . & $\mathrm{P}>|\mathrm{z}|$ & Coef. & $\mathrm{P}>|\mathrm{z}|$ \\
\hline hhsize & .0518549 & 0.429 & 0.0100861 & 0.837 \\
\hline gender & .6547572 & 0.15 & -0.2067374 & 0.585 \\
\hline age & .0100157 & 0.501 & 0.001284 & 0.904 \\
\hline educ1 & -.0676504 & 0.037 & -0.0230462 & 0.398 \\
\hline hhelectric & .614853 & 0.244 & 1.285614 & 0.003 \\
\hline priocupation & -.031477 & 0.786 & -0.156906 & 0.158 \\
\hline foruseyrs & -.0094808 & 0.558 & 0.0365002 & 0.011 \\
\hline distpmkmins & .0101552 & 0.137 & 0.005182 & 0.434 \\
\hline mkttrans & -.051213 & 0.907 & -0.2587074 & 0.441 \\
\hline nr5 & $-3.69 \mathrm{e}-07$ & 0.079 & $3.11 \mathrm{E}-07$ & 0.278 \\
\hline extcvisit & .0473545 & 0.579 & 0.0251364 & 0.623 \\
\hline springprec & .2724693 & 0 & 0.0085118 & 0.606 \\
\hline summerprec. & -.0421431 & 0 & -0.028148 & 0.004 \\
\hline fallprec. & -.1923181 & 0 & 0.0106378 & 0.35 \\
\hline winterprec. & .0494629 & 0.156 & 0.1040578 & 0.052 \\
\hline wintertemp. & & & 0.1150451 & 0.053 \\
\hline _cons & 10.89785 & 0 & 1.921054 & \\
\hline Chi2 & 41.374 & 0 & 50.372 & 0 \\
\hline
\end{tabular}

\section{DISCUSSION}

The results on the perception of climate change resonates with those of other studies in different parts of Nigeria; Apataet al. (2009) in Western Nigeria, Idrisaet al. (2012) in part of northern Nigeria, Falakiet al. (2013) in North Central Nigeria. Also a study in 11 African countries by Madison (2007) indicates that significant numbers of farmers believed average temperatures had increased and rainfall levels had decreased with change in the timing of the rains. The same is the case in several other studies of scholars across the globe which strongly resonate with the findings in this work: de Wit (2006) in 11 African countries, (Gbetibouo, 2008) in South Africa, Mertz et al. (2009) in Senegal, Jennings and Magrath (2009), Akponikpèet al. (2010) in Benin, Burkina Faso, Ghana, Advancing Capacity to Support Climate Change Adaptation (ACCCA) (2010)in Ethiopia, di Falco et al. (2011) in Ethiopia, Nyangaet al. (2011) in Zambia, Mandleni and Anim (2011) in South Africa,Leviston and Walker (2011) in Australians, Mengistu (2011) in Ethiopia,Acquahde Graft (2011) in Ghana, Kemausuoret al. (2011) in Ghana, Acquah-de Graft and Onumah (2011), Gandureet al. (2012) in South Africa, Habibaet al. (2012) in Bangladesh, Grandureet al. (2013) in South Afica, Sahu and Mishra (2013) in India , Shankar et al. (2013) in India and African Technology Policy Studies Network, ATPS (2013) in Ethiopia, all indicate that between 70 to $98 \%$ of respondents in their studies affirmed their perceptions of climate change in different forms, thus, underscoring a global consensus about the level of awareness and agreement on the prevalence of climate change phenomenon. In 
essence local knowledge, perception and experience have helped to advance understanding of climate change and its impacts and is critical in guiding policy decisions and responses on adaptation.

Table 5: Marginal effects from the logit model

\begin{tabular}{lllll}
\hline & $\begin{array}{l}\text { Notice of } \\
\text { change }\end{array}$ & climate & Adaptation & decision \\
\hline Variables & dy/dx & $\mathrm{P}>|\mathrm{z}|$ & dy/dx & $\mathrm{P}>|\mathrm{z}|$ \\
hhsize & 0.00456 & 0.453 & 0.0014638 & 0.837 \\
gender & 0.057579 & 0.225 & -0.0300042 & 0.584 \\
age & 0.000881 & 0.519 & 0.0001863 & 0.904 \\
educ1 & -0.00595 & 0.133 & -0.0033447 & 0.395 \\
hhelectric & 0.054069 & 0.304 & 0.1865837 & 0.002 \\
priocupation & -0.00277 & 0.788 & -0.0227721 & 0.155 \\
foruseyrs & -0.00083 & 0.569 & 0.0052974 & 0.009 \\
distpmktmins & 0.000893 & 0.213 & 0.0007521 & 0.432 \\
mkttrans & -0.0045 & 0.907 & -0.0375467 & 0.441 \\
nr5 & $-3.25 \mathrm{E}-08$ & 0.166 & $4.51 \mathrm{E}-08$ & 0.271 \\
extcvisit & 0.004164 & 0.591 & 0.0036481 & 0.623 \\
springp & 0.023961 & 0.025 & 0.0012353 & 0.606 \\
summerp & -0.00371 & 0.05 & -0.0040852 & 0.003 \\
fallp & -0.01691 & 0.033 & 0.0015439 & 0.346 \\
winterp & 0.00435 & 0.225 & 0.0151021 & 0.05 \\
springt & & & -0.0049157 & 0 \\
summert & & & -0.0065046 & 0 \\
fallt & & & -0.0017671 & 0 \\
wintert & & & 0.0166967 & 0.052 \\
\hline
\end{tabular}

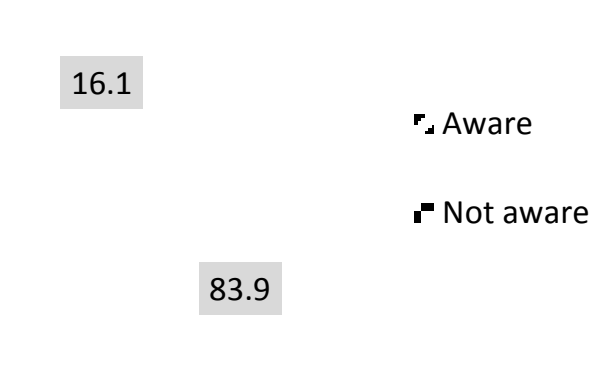

Figure 6: Awareness of changes in forest resources in all the regions

This in line with the experiences of Salick and Byg (2009) in China,, Tucker et al. (2010) in Central America and Mexico, Maddison (2007) in African countries, Bryan et al. (2009) in South Africa and Ethiopia and Kelkaret al.(2008) in India. These finding are reinforced by the fact that a greater percentage of the respondents at least have an idea of what climate change is all about (Fig. 4), a sover $60 \%$ of them actually use the phrase 'climate change' in their description of the phenomenon. It goes to show the high level of understanding of the concept of climate change phenomenon in Nigeria. So what is needed is a stakeholders synergy to take good advantage of this level of awareness to build on the understanding of the people about climate change to enforce positive behaviours with appropriate incentives; livelihood options, social capital, policies and programmes and even direct interventions. In this way the resilience and adaptive capacities of the rural poor can be enhanced for the greater benefit of the society and the ecosystem. The negative association between level of education, level of income and climate change perception is not surprising as those with less education and most likely lower income are closer to the agro - forestry system than those with higher income and income as the former depend more on these natural resource base more than the later. So they are likely to be more conversant with any incidence of climate change and changes in forest resource use. The later are more engaed in other employment opportunities and less on the natural resource base system and their involvement in forest resource use are in most cases for leisure. With respect to the factors influencing the likelihood of adoption, the result on the positive effect of the number of years of forest use (experience) resonates with those of Shortle and Miranowaski (1986), Gbetibouo (2008), Ayanwuyiet al. (2010, Dhaka et al.(2010),BaffoeAsare(2013), Mudzonga (2012), Rana et al. (2012), Shankar et al. (2013), who found that experience has a positive effect on adoption decision. Thus, Ofuoku (2011) opine that those who have many years of farming experience have interacted much more with the climate in relation to their activities and therefore, have good knowledge of environmental factors as they relate to their daily operations. It is not surprising that households with access to electricity are more likely to adapt to climate change than those that haven't. Access to electricity in Nigeria is somewhat a sign of being well-off, which is associated with better enlightenment, education and to some extent wealth. Thus they are more likely to be amenable to taking decision to adapt to climate change than those without electricity access. This is because, they are better unformed, especially as they are able to watch and get information about climate change from their televisions; with superior information and knowledge they are able to make informed choices. This result agrees with that of Bryan et al. (2013) that those households with access to electricity (an indicator of wealth) are more likely to adopt adaptation practices in Kenya.Itis also in agreement with the views of Cinneret al. (2009) and Marshall et al.(2010) that household access to electricity reinforces social and climate change resilience. With respect to climate change perception, that spring rainfall (late dry season and beginning of rainy season) favored climate change perception is very unique. This is because the result tallies exactly with the situation on ground in Nigeria. During this period the dry 
season has peaked and in most cases is driest and hottest period of the year in different parts of the country as is shown in table 3 ; showing the highest minimum and maximum temperature record in the year. Thus, it is therefore unusual to see heavy rains falling at this period of the year. So when suddenly it does, year after year for a long period of time, it then means that something is wrong. Such rains are very deceptive as they are followed by long periods of spell, such that those who ever tried to plant with the early rains get their crops scotched up. So, farmers have come to term with the fact that they have to wait till the rains are established and the soil is wet enough for them to plant. Thereafter, in the following months of June to November (summer and autumn), the results showed that they negatively influence climate change perception, as rainfall in these seasons are normal and are as expected. Except that sometimes they are heavier than normal with a lot of flood. This finding is reinforced by the result on the decision to adapt to climate change (Table 5), which also had a negative likelihood in the summer.In addition, too much rain during the summer inhibit forest activities by preventing access to the forest and other activities. It is also worthy of note that winter rainfall (December February) encourages the decision to adopt different types of adaptation strategies. This is another key finding that is very vital in the climate change adaptation framework, especially in Nigeria. Because the continued existence of rainfall up to this period is very encouraging to all farmers across the country to get into late planting of some crops, especially vegetables. Thus farmers are encouraged to produce food all the year round. In the absence of rain at this period some farmers who can afford it use irrigation. It is therefore very vital to target this period of the year by government and development practitioners to provide alternative sources of water for the farmers in order to empower them to boost their output. These results are in conformity with the findings of different scholars in different parts of the tropics with respect to climate change perceptionsof changing rainfall and temperature and how it affects their behavior, as has been earlier discussed.

\section{CONCLUSION}

For an effective design and implementation of any climate change adaptation policy, there is the need for adequate information and knowledge about the level of understanding of the people about the nature and extent of vulnerability, their perception of the level of risks they are exposed to, the different kinds of strategies in situ and the factors affecting their adaptation decisions. This study like those of other scholars across the globe shows a very high level of climate change perception and awareness in Nigeria. It indicates that though level of education and income inhibit climate change perception, on the contrary access to electricity and years of experience are valuable assets towards innovation adoption. Thus, those that are well to do are less likely to perceive climate change as they are less dependent on forest resources than those that are not. Furthermore, spring rainfall encourages climate change perception due to its unusual nature in recent times, while summer rainfall inhibits climate change perception and adaptation decision among the forest poor. There is therefore the need for stakeholders to synchronize these information for appropriate adaptation interventions at the right time with focus on the forest poor in order to build their resilience to climate change and their capacity to adapt.

\section{REFERENCES}

Acquah-de Graft, H. (2011) Farmers' perceptions and adaptation to climate change: a willingness to pay analysis. Journal of Sustainable Development in Africa, 13, 5:150-161.

Acquah-de Graft, H., and Onumah, E. (2011) Farmers' perceptions and adaptations to climate change: An estimation of willingness to pay. Agris, 3, 4:31-39.

Advancing Capacity to Support Climate Change Adaptation (ACCCA) (2010) Farm - level climate change perception and adaptation in drought prone areas of Tigray, Northern Ethiopia, Vol. 3. Project No. 093.

Akinwumi A. A., Mbilab, D.,Nkamleub, G. B. and Endamana, D. (2000) Econometric analysis of the determinants of adoption of alley farming by farmers in the forest zone of southwest Cameroon. Agriculture, Ecosystems and Environment 80:255265.

Akponikpe, P., Johnston, P. andAgbossou, E. K. (2010).Farmers' perceptions of climate change and adaptation strategies in sub-Sahara West Africa.2nd International Conference on Climate, Sustainability and Development in Arid Regions, Fartaleza-Ceara, Brazil.

African Technology Policy Studies Network, (ATPS) (2013) Farmers' perception and adaptive capacity to climate change and variability in the upper catchment of Blue Nile, ATPS working paper No. 77.

Apata, T. G., Samuel, K. D., andAdeola, A. O. (2009).Analysis of climate change perceptions and adaptation among arable food crop farmers in South Western Nigeria. Contributed paper presented at 23rd Conference of International Association of Agricultural Economists, Beijing, China, August 1622, 2009

As faw, S. and Lipper, L. (2011) Economics of PGRFA management for adaptation to climate change: a review of selected literature. FAO background study paper no. 60

Ayanwuyi, E., Kuponiyi, F., Ogunlade, A. and Oyetoro J.O. (2010) Farmers perception of impact of climate changes on food crop production in Ogbomosho Agricultural Zone of Oyo State, Nigeria. Global Journal of Human Social Science, 10, 7:33-39.

Baffoe-Asare, R., Danquah, J. A. and Annor-Frempong, F. (2013) Socioeconomic factors influencing adoption of codapec and cocoa high-tech 
technologies among small holder farmers in central region of Ghana. American Journal of Experimental Agriculture, 3, 2:277-292.

Beilin, R., Sysak, T. and Hill, S. (2012) Farmers and perverse outcomes: the quest for food and energy security, emissions reduction and climate adaptation. Global Environmental Change 22:463-471.

Belliveau, S., Bradshaw, B., Smit, B., Reid, S., Ramsey, D., Tarleton, M. and Sawyer, B.(2006)

Farm-level adaptation to multiple risks: climate change and other concerns.Occasional Paper, 27.University of Guelph, Canada.

Below, T.B., Mutabazi, K.D., Kirschke, D., Franke, C., Sieber, S., Siebert, R. and Tscherning, K. (2012) Can farmers' adaptation to climate change be explained by socioeconomic household-level variables? Global Environmental Change 22:223-235.

Bradshaw, B., Dolan, H. and Smit, B. (2004) Farm-level adaptation to climatic variability andchange: crop diversification in the Canadian Prairies. Climatic Change 67:119-141.

Brklacich, M., McNabb, D., Bryant, C. and Dumanski, I. (1997) Adaptability of agriculture systems to global climatic change: a Renfrew County, Ontario, Canada Pilot Study. In: Iibery, B., Chiotti, Q., Richard, T. (Eds.), Agricultural Restructuring and Sustainability: A Geographical Perspective. CAB International, Wallingford, CT.

Bryan, E., Deressa, T.T., Gbetibouo, G.A. and Ringer, C. (2009) Adaptation to climate change in Ethiopia and South Africa: Options and constraints. Environmental Science and Policy 12:413-426.

Bryant, R. C., Smit, B., Brklacich, M., Johnston, R. T., Smithers, J., Chiotti, Q., et al. (2000) Adaptation inCanadian agriculture to climatic variability and change. Climatic Change, 45:181-201.

Burton, I. (1997) Vulnerability and adaptive response in thecontext of climate and climate change. Climatic Change 36,185-196.

Cinner, J., M. M. P. B. Fuentes, and H. Randriamahazo. 2009. Exploring social resilience in Madagascar's marine protected areas. Ecology and Society 14(1): 41

de Wit, M. (2006). The perception of and adaptation to climate change in Africa, CEEPA discussion Paper No. 10, CEEPA, University of Pretoria.

Deci, E. L., \& Ryan, R. M. (1985).Intrinsic motivation and self-determination in human bahavior. New York: Plenum.

De Graaff, J., Amsalu, A., Bodner, F., Kessler, A., Posthumus, H., \&Tenge, A. J. (2008). Factors influencingadoption and continued use of long-term soil and water conservation measures in five developing countries. Applied Geography, 28: 271280. http://dx.doi.org/10.1016/j.apgeog.2008.05.001

De Young, R. (1996). Some psychological aspects of a reduced consumption lifestyle: The role of intrinsicsatisfaction and competence. Environment and Behavior, 28: 358-409.

Dhaka, B. L., Chayal, K. and Poonia, M.K. 2010. Analysis of Farmers'Perception and Adaptation Strategies to Climate Change, LibyanAgricultural Research Center Journal International, 1 (6): 388390.

Di Falco, S., Mahmud, Y. Gunnar, K., Claudia R. (2011) Estimating the Impact of Climate Change on Agriculture in Low-Income Countries: Household
Level Evidence From the Nile Basin, Ethiopia. Environ Resource Econ, DOI 10.1007/s10640-0119538-y

Diggs DM. Drought experience and perception of climatic change among Great Plains farmers. Great Plains Research 1991;1:114-32.

Dong, D., Saha, A. (1998) He came, he saw, (and) he waited: an empirical analysis of inertia in technology adoption. Appl. Econ. 30: 893-905.

Edwards-Jones, G., \& McGregor, M. J. (1994). The necessity, theory and reality of developing Models offarm house holds.In J.B.Dent \& M.J.McGregor(Eds.),Ruraland farming systems analysis-European Perspectives (pp. 338-352). Wallingford, UK: CAB.

Esser, P., (1999) Akzeptanz-was stecktdahinter? "UberlegungenzurAkzeptanzdebatte inNaturschutz und Landschaftsplanung. Diplomarbeit am Institutf ur

Falaki, A. A., Akangbe, J. A. and Ayinde, O. E. (2013) Analysis of Climate Change and Rural Farmers' Perception in North Central Nigeria. J Hum Ecol, 43(2): 133-140

FAO (2007). Food and Agricultural Organization of the United Nations. Retrieved from www.fao.org/nr/water/aquastat/countries/botswana/in dex.stm

Feder, G., Just, R. E., \& Zilberman, D. (1985). Adoption of agricultural innovation in developing countries: A survey World Bank staff working papers, 542. Washington, DC: The World Bank.

Gandure, S., Walker, S., \& Botha, J. J., (2012). Farmers'perceptions of adaptation to climate change and water in a South African rural community.Environment Development. Retrieved from http://dx.doi.org/10.1016/j.endev.2012.11.004

Gbetibouo, G. A. (2018) Understanding Farmers' Perceptions and Adaptations to Climate Change and Variability: The Case of the Limpopo Basin, South Africa, IFPRI Discussion Paper 15-8, (Washington, DC:

Giampietro, M. (1997).Socioeconomic constraints to farming with biodiversity. Agriculture, Ecosystems and Environment, 62:(2-3), 145-167.

Granjon, D. (1999) Ennque^tes et resultants sur l'adaptation del'agriculture aux different types de stress: le cas de la zonede Napierville, Research Report Submitted to Singh, B. andBryant, C.R. as Part of a Research Contract withAtmospheric Environment Services, Environment Canada, Downsview.

Guerin, T. (1999) An Australian perspective on the constraints to the transfer and adoption of innovations in land management. Environ. Conserv. 24 (4): 289-304.

Haden, V.R., Niles, M.T., Lubell, M., Perlman, J., Jackson, L., 2012. Global and local concerns: what attitudes motivate farmers to mitigate and adapt to climate change. PLoS ONE 7:e52882

Habib, U., Shaw, R. and Takeuch, Y. (2012) Farmers' perception and adaptation pract ices to cope with drought: Perspectives from Northwestern Bangladesh. International Journal of Disaster Risk Reduction $1 \quad 72 \quad-84 . \quad$ http://dx.doi.org/ 10.1016/j.ijdrr.2012.05.004.

Idrisa, Y. L., ,B. O. Ogunbameru1, A. A. Ibrahim1 and D. B.Bawa1 Analysis of Awareness and Adaptation to 
Climate Change among Farmers in the Sahel Savannah Agro-ecological Zone of Borno State, Nigeria. British Journal of Environment \& Climate Change2 (2): 216-226, 2012

Jamnick, S.F., Klindt, T.H. (1985). An Analysis of 'notillage' Practice Decisions. Department of Agricultural Economics and Rural Sociology, University of Tennessee, USA.

Jennings, S. and Magrath, J. (2009) What happened to the seasons? Oxfam research report. Available online at:

http://www.oxfam.org.uk/resources/policy/climate_c hange/research-where-are-theseasons.html

Kemausuor, F., Dwamena, E., Ato Bart-Plange and Nicholas KyeiBaffour (2011) Farmers' Perception of Climate Change in the EjuraSekyedumaseDistrict of Ghana, ARPN Journal of Agricultural and Biological Science, Vol.6, No.10:26-37.

Kessler, C.A. (2006) Decisive key-factors influencing farm households' soil and water conservation investments. Applied Geography 26: 40-60

Kessler, J. J. (2003). Working towards SEAN-ERA, a framework and principles for integrating environmental sustainability into planning Tropical resource management papers, 43

Kelkar, U., Narula, K.K., Sharma, V.P., Chandna, U., (2008). Vulnerability and adaptation to climate variability and water stress in Uttarakh and State, India. Global Environmental Change 18: 564-574.

Lapar, A.L., Pandey, S. (1999). Adoption of soil conservation: the case of the Philippine uplands. Agric. Econ. 21: 241-256.

Leagans,J.P.(1979).Adoptionofmodernagriculturaltechno logybysmallfarmoperators:Aninterdisciplinarymodel for researchers and strategy builders. Ithaca, NY: Department of Education, New York College ofAgriculture and Life Sciences, Cornell University.

Llewellyn, R. S. (2007) Information quality and effectiveness for more rapid adoption decisions by farmers. Field Crops Research 104: 148-156

Lubell, M., Zahran, S., Vedlitz, A. (2007). Collective action and citizen responses to global warming. Polit. Behav. 29: 391-413.

Maddison, D.J., 2007. The Perception of and Adaptation to Climate Change in Africa.World Bank Policy Research Working Paper no. 4308. Available from: / www.ceepa.co.za/docs/CDPNo10.pdf, accessed 23/03/2011 S

Mandleni, B., \&Anim, F. (2011).Perceptions of Cattle and Sheep Framers on Climate Change and Adaptations in the Eastern Cape Province of South Africa. Journal of Human Ecology, 34(2): 107-112.

Mano, R. and C. Nhemachena (2007) Assessment of the economic impacts of climate change on agriculture in Zimbabwe: a Ricardian approach. Policy Research W orking Paper No.4292. World Bank, Washington DC

Marshall, N. A., Marshall, P. A., Tamelander, J., Obura, D., Malleret-King, D., \&Cinner, J. E. (2010).A Framework for Social Adaptation to Climate Change: Sustaining Tropical Coastal Communitites [sic] and Industries. IUCN.

Mbaga-Semgalawe, Z. and HenkFolmer (2000) Household adoption behavior of improved soil conservation: the case of the North Pare and West Usambara Mountains of Tanzania. Land Use Policy 17 (2000) 321\}336
McDonald, M., Brown, K. (2000). Soil and water conservationprojects and rural livelihoods: options for design and researchto enhance adoption and adaptation. Land Degrad. Dev. 11: 343-361.

Mengistu, D. K. (2011) Farmers' perception and knowledge of climate change and their coping strategies to the related hazards: Case study from Adiha, central Tigray, Ethiopia. Agricultural Sciences, Vol.2, $\quad$ No.2, 138-145, doi:10.4236/as.2011.22020

Mertz, O., Mbow, C., Reenberg, A., \& Diouf, A. (2009). Fermers' Perceptions of Climate Change and Agricultural Adaptation Strategies in Rural Sahel. Environmental Management, 43:(2009), 804-816

Mudzonga, E. (2012) Farmers' Adaptation to Climate Change in Chivi District of Zimbabwe. Paper Presented at TRAPCA's Trade Policy Research Forum, 2012 on 'African Trade under Climate Change and the Green Economy, 6-7th August, 2012, Arusha, Tanzania.

Nhemachena, C. \& Hassan, R. (2007) Micro-level analysis of farmers' ${ }^{6}$ adaptation to climate change in southern Africa. IFPRI Discussion Paper 00714. Washington, D.C.: International Food Policy Research Institute.

Nicholas, K., Durham, W. (2012). Farm-scale adaptation and vulnerability to environmental stresses: insights from winegrowing in Northern California. Global Environmental Change 22: 483-494.

Niles, M. T., Mark Lubella , Van R. Haden (2013) Perceptions and response $s$ to climate policy risks among Calif orniafarmers . Global Environmental Change 23: 1752-1760.

Nyanga, P., Johnsen, F., Aune, J., \&Kahinda, T. (2011). Smallholder Farmers' Perceptions of Climate Change and Conservation Agriculture: Evidence from Zambia. Journal of Sustainable Development, 4(4), 73-85. http://dx.doi.org/10.5539/jsd.v4n4p73

Ofuoku, A.U., 2011. Rural farmers' perception of climate change in central agricultural zone of Delta state, Nigeria. Indonesian Journal of Agricultural Science 12 (2), 63-69

Osbahr, H., C. Twyman, W. N. Adger, and D. S. G. Thomas. (2008). Effective livelihood adaptation to climate change disturbance: scale dimensions of practice in Mozambique. Geoforum 39 (6): 19511964.

Osbaldiston, R., \& Sheldon, K. M. (2003). Promoting internalized motivation for environmentally responsible behaviour: A prospective study of environmental goals. Journal of Environmental Psychology, 23: 349-357.

Pannell D. (1999). Economics, extension and the adoption of land conservation innovations in agriculture. International Journal of Social Economics 26: 999-1012.

Pannell, D.J. (1999). Social and economic challenges to the development of complex farming systems. Agroforestry Syst. 45: 393-409

Rana, S., Priyanka Parvathi and Hermann Waibel (2012) Factors Affecting the Adoption of Organic Pepper Farming in India. Paper presented at the Conference on International Research on Food Security, Natural Resource Management and Rural Development organised by: Georg-August Universität Göttingen and University of Kassel-Witzenhausen. Tropentag 2012, Göttingen, Germany September 19-21, 2012 
Sahua, N. C. and Mishra, D. (2013) Analysis of Perception and Adaptability Strategies of the Farmers to Climate Change in Odisha, India. APCBEE Procedia 5: 123 - 127.

Salick, J., Byg, A., 2009. Local perspectives on a global phenomenon - climate change in Eastern Tibetan villages. Global Environmental Change 19, 156-16

Sattlera,C., Uwe Jens Nagel (2008) Factors affecting farmers' acceptance of conservation measures-A case study from north-eastern Germany. Land Use Policy 27: (2010) 70-77.

Shankar, R. K., Nagasree, K., MaruthiSankar, G.R., Prasad, M.S., Raju, B.M.K., Subba Rao, A.V.M. and Venkateswarlu, B. (2013). Farmers Perceptions and Adaptation Measures towards Changing Climate in South India and Role of Extension in Adaptation and Mitigation to Changing Climate. Extension Bulletin No. 03/2013.Central Research Institute for Dryland Agriculture, Hyderabad.p 28.

Shortle, J.S., Miranowski, J.A. (1986). Effect of Risk Perceptions and Other Characteristics of Farmers and Farm Operations on the Adoption of Conservation Tillage Practices. Department of Agricultural Economics, University of Pennsylvania State University, USA.

Smit, B. and J. Wandel (2006) Adaptation, adaptive capa city and vulnerability. Global Environmental Change pp. 282-292.

Smit, B., Skinner, M.W. (2002). Adaptations options inAgriculture to climate change: a typology. Mitigation and Adaptation Strategies for Global Change 7:85-114.

Smit, B., McNabb, D., Smithers, J. (1996). Agricultural adaptationto climatic variation. Climatic Change 33: $7-29$.

Smithers, J., Smit, B. (1997). Human adaptation to climaticvariability and change. Global Environmental Change 7 (3): 129-146.

Soule, J.M., Tegene, A., Wiebe, D.K. (2000). Land tenure and the adoption of soil conservation practices. Am. J. Agric. Econ. 82 (4): 993-1005.

Sunding, D. and Zilberman, D. (2010) The agricultural innovation process: research and technology adoption in a changing agricultural sector. In Pingali P. R and Evanson R. E., Vo. 4, Elsevier, Holland.

Tenge, A. J., De Graaff, J., \& Hella, J. P. (2004).Social and Economic Factors Affecting the Adoption of Soil and Water Conservation in West Usambara Highlands, Tanzania. Land Degradation and Development, 15, 99-114. http://dx.doi.org/10.1002/ldr.606

Thomas, D., Twyman, C., Osbahr, H., \& Hewitson, B. (2007). Adaptationto climate change and variability: Farmer responses to intra-seasonal precipitation trends in South Africa. Climatic Change, 83 301-322.
Tucker, C.M., Eakin, H., Castellanos, E.J. (2010). Perceptions of risk and adaptation: coffee producers, market shocks, and extreme weather in Central America and Mexico. Global Environmental Change 20: $23-32$

Vanclay, F., \& Lawrence, G. (1994). Farmer rationality and the adoption of environmentally sound practices; aritiqueoftheassumptionsoftraditionalagriculturalexte nsion.EuropeanJournalforAgriculturalEducationand Extension, 1:, 59-90.

Vogel, C., O'Brien, K. (2006). Who can eat information? Examining the effectiveness of seasonal climate forecastsand regional climate-risk management strategies. ClimateResearch 33: 111-122.

West, C. T., Roncoli C, Ouattara F. (2007). Local perceptions and regional climate trends on the Central Plateau of Burkina Faso. Land Degradation \& Development 19:289-304.

Wheeler, A. Zuo , H. Bjornlund (2013)Farmers' climate change belie fs and adaptation strategies for a water scarc e future in Australia S. Global Environmental Change 23 (2013) 537-547.

Wortman,C.Kirungu,B. (1999). Adoption of Legumes for Soil Improvement and Forage by Smallholder Farmers in Africa. In: Stur, W., Horne, P., Hacker, J., Kerridge, P. (Eds.), Working with Farmers: The Key to Adoption of Forage Technologies. Proceedings of International Workshop, Cagayan de Oron City, Philippines, October 12-15, 1999, ACIAR Proceedings No. 95, pp. 140-148.

Wubeneh, N. G. and Sanders, J.H. (2006) Farm-level adoption of sorghum technologies in Tigray, Ethiopia. Agricultural Systems 91: 122-134.

Yanda, P. (2007) Africa, in Parry, M. L., Canziani, J. P., van der Linden, P. J. and Hanson, C.E. (Eds.): Climate Change 2007: Impacts, Adaptation an d Vulnerability. Cambridge University Press, Cambridge.

Zbinden, S. and Lee, D. (2005). Paying for Environmental Services: An Analysis Of Participation in Costa Rica's PSA Program. World Development Vol. 33, No. 2, pp. 255-272. doi:10.1016/j.worlddev.2004.07.012.

Ziervogel, G., Bithell, M., Washington, R., Downing, T. (2005). Agent-based social simulation: a method for assessing the impact of seasonal climate forecasts among smallholder farmers. Agricultural Systems 83 (1): $1-26$ 